\title{
PM2.5 induced cardiac hypertrophy via CREB/GSK3b/SOS1 pathway and metabolomics alterations
}

\author{
Kuan-Lun $\mathrm{Li}^{1}$ and Yen-Chang Lin ${ }^{1}$ \\ ${ }^{1}$ Graduate Institute of Biotechnology, Chinese Culture University, Taipei, Taiwan \\ Correspondence to: Yen-Chang Lin, email: lycnthu@gmail.com \\ Keywords: particulate matter; blood pressure; action potentials; polysaccharides; electrocardiography \\ Received: December 30, $2017 \quad$ Accepted:May 07, $2018 \quad$ Published: July 20, 2018 \\ Copyright: Li et al. This is an open-access article distributed under the terms of the Creative Commons Attribution License 3.0 \\ (CC BY 3.0), which permits unrestricted use, distribution, and reproduction in any medium, provided the original author and source \\ are credited.
}

\section{ABSTRACT}

The particle matter with diameter less $2.5 \mu \mathrm{m}$ (PM2.5) easier to adsorb toxic substance, and interfere with pulmonary gas exchange. In this study, cardioprotective effects of low molecular weight (LMW) fucoidan in cardiac hypertrophy subjects induced by PM2.5 exposure was conducted by measuring QT interval, Blood pressure, cardiac structure, metabolites and proteins expression in different organs. After PM2.5 exposure, increase in blood pressure, abnormal cardiac function (Prolongation of Action Potential Duration and QT Interval), and structral remodeling (cardiac hypertrophy and fibrosis) were recorded. Fucoidan supplement in consecutive 28 days can reduce the damage to myocardial injury caused by PM2.5. Clearance effect of fucoidan in serum, heart, kidney, lung and liver was found due to organic and inorganic compounds reduced SOS1, CREB, GSK3b, and GRB2 protein level were changed under PM2.5 exposure. Whereas, only CREB level was reduced after fucoidan treatment. Metabolic alteration was also determined that PM2.5 severely damage cardiac tissue and compromise its function. After treatment with fucoidan, the cardiac function was significantly recovered. Our finding demonstrated that LMW could enhance the cardiac status of mice with PM2.5 exposures by rescued QT interval prolongation, action potential and cardiac hypertrophy, and cardiac fibrosis decline.

\section{INTRODUCTION}

Particle matter (PM)is any particle suspended in the air. According to the size of the particle, it is classified into PM10, PM2.5, and PM1.0 with particle size smaller than $10 \mu \mathrm{m}, 2.5 \mu \mathrm{m}$, and $1 \mu \mathrm{m}$, respectively [1-3]. According to an updated report of American Heart Association (AHA), deaths related to cardiac malfunction and PM2.5 exposure are significantly associated [4]. In previous control-exposure studies, black carbon, titanium dioxide or vanadium pentoxide was used as sole exposure source of PM2.5, however, they cannot reflect the complex mixture of real PM2.5 which is varied according to location and time [5]. The current strategy is to use socalled concentrated ambient particles (CAPs) to get rid of above problems [5].
Fucoidan has been identified firstly by Kylin [6]. It can be extracted from various types of brown algae $[7,8]$. Depending on the extraction method and algae species, fucoidan biological and chemical characteristics would differ from one another [9]. Fucoidan has been extensively studies recently in anti-cancer property and others areas [10-13]. The proportion of sulfate and molecular weight of fucoidan are highly associated with its biological function $[14,15]$. The small molecular weight of fucoidan ( $\mathrm{MW}<30 \mathrm{kDa})$ has high biological function and vice versa [16-18]. The cardioprotective effects of fucoidan was demonstrated previously [19, 20]. This study aims to investigate on the underlying mechanism of LMF in ameliorating cardiac function afterconsecutive 28 days exposed to PM2.5 in rodent subjects. 


\section{RESULTS}

\section{Inorganic compounds in CAPs PM2.5}

We detected the concentration of inorganic compounds (heavy metal) in PM2.5, such as $\mathrm{Cd}, \mathrm{As}, \mathrm{Pb}$, $\mathrm{Cu}$, and $\mathrm{Hg}$ by using iCAP -Q ICP-MS (Thermo Fisher Scientific, Waltham, MA, USA).

Our results indicated that $\mathrm{Pb}$ had the highest concentration $(560 \pm 1.59 \mathrm{ppm})$ in PM2.5. Cu as well as As were also had higher concentrations $(180 \pm 1.36$, and $94.5 \pm 2.04 \mathrm{ppm}$ ) (Figure 1A).

\section{Inorganic compounds in mice serum and organs}

Heavy metals $(\mathrm{Cd}, \mathrm{As}, \mathrm{Pb}, \mathrm{Cu}$, and $\mathrm{Hg})$ in mice serum and organs were detected by iCAP -Q ICP-MS (Thermo Fisher Scientific, Waltham, MA, USA). The concentration of heavy metal in clean is $\mathrm{Pb}<100 \mathrm{ng} / \mathrm{m} 3$, As $=1.5-53 \mathrm{ng} / \mathrm{m} 3, \mathrm{Cu}<200 \mathrm{ng} / \mathrm{m} 3$. Our results indicated that concentration of 5 inorganic compounds decreased after fucoidan treartment.

Inorganic compound concentration in serum, heart, kidney, lung, and liver were all high in $\mathrm{Pb}$, and $\mathrm{Cu}$. After fucoidan supplement, the concentration of $\mathrm{Pb}$, and $\mathrm{Cu}$ decreased siginificantly (Figure 1B-1F).

\section{H\&E staining and masson's trichrome staining}

The heart hypertrophy and fibrosis induced by PM2.5 were observed in PW group but not in control group. After 28 days treatment with fucoidan both heart morphology and fibrosis of subjects were significantly ameliorated (Figure 2A, 2B).

In summary, histological examination findings might considerably clarify the malfunction of cardiac system such as QT interval and action potential alteration via structural changes in mice exposed to PM2.5 and these changes could dramatically reverse to almost normal condition when treated with LMF.

\section{Effect of LMF on systolic and diastolic pressure in PM2.5-exposed mice}

The results of systolic and diastolic pressure in PM2.5-exposed mice, treated with LMF shown significant reduction relative to control group. In the beginning of this experiment, there were no differences among all 3 groups. Besides, systolic and diastolic pressure all reduced after LMF treatment (systolic pressure at week 4, Ctrl:111.4 \pm 0.89 , PW: $167 \pm 1.82$, and PF:139.9 \pm 2.28 ; diastolic pressure at week 4, Ctrl:62.8 $\pm 1.3, \mathrm{PW}: 105 \pm 1.64$, and $\mathrm{PF}: 85.1 \pm 1.14$ ) (Figure 3).
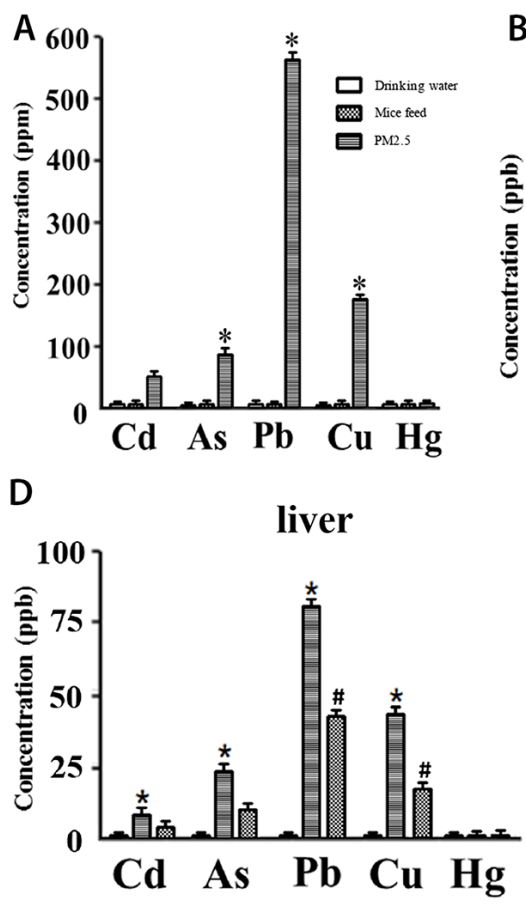

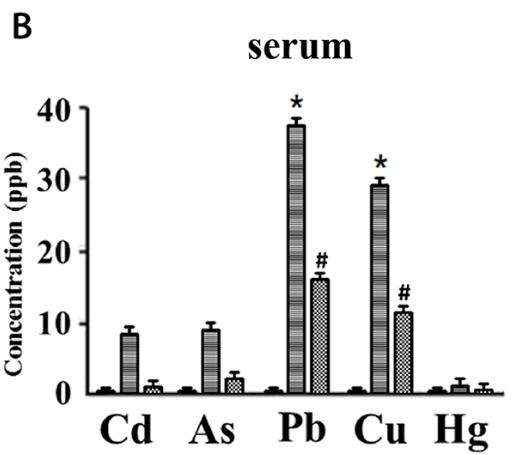

$\mathrm{E}$

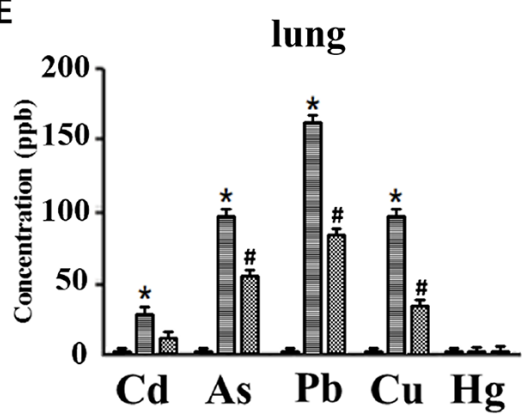

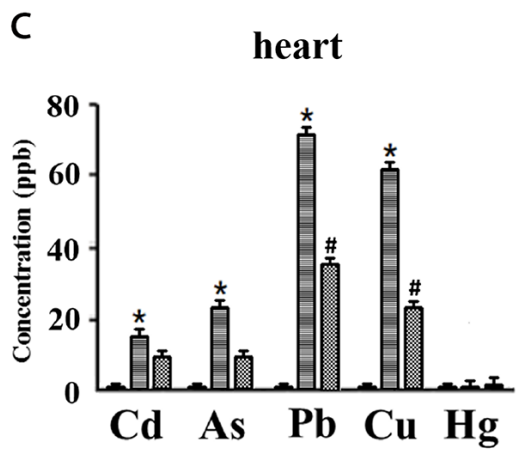

F

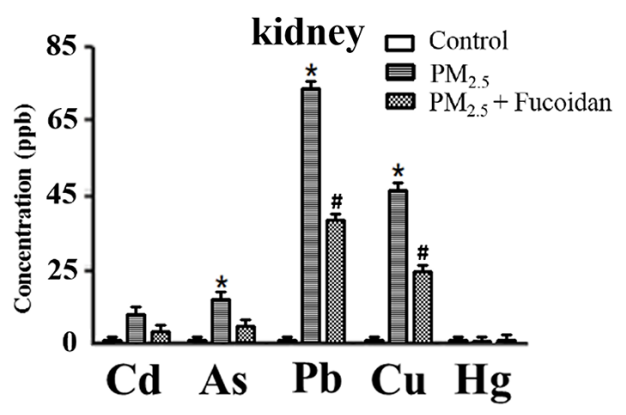

Figure 1: Concentration of 5 heavy metals in mice drinking water, feed, and PM2.5 (A). Concentration of 5 heavy metals in serum (B), heart (C), liver (D), lung (E), kidney (F) of 3 groups (Control, PM2.5, and PM2.5 + Fucoidan). PM2.5 had significantly higher concentration of $\mathrm{Pb}, \mathrm{Cu}$, and As relative to drinking water and feed. These results show that PM2.5 is the source of heavy metal compounds which may affect functions of heart and other organs ( ${ }^{*}$ for comparison with drinking water and feed, the values displayed as mean $\pm \mathrm{SD}$, $\mathrm{P}<0.05)$. 


\section{Effect of LMFon QT interval and Action Potential in PM2.5-exposedmice}

Prolonged QT interval was determined in PM2.5exposed group (PW) $(0.062688 \pm 0.0049)$ relative to control group (0.039532 \pm 0.0036$)$. QT interval reduced when treated with LMF (PF300:0.043126 \pm 0.0065 ). Consistently to the results of QT interval prolonged in PM2.5-exposed model, the action potential duration in myocytes of mice in PM2.5 group shown significant increment relative to control group. Action potentialdecreased in PM2.5-exposed mice treated with LMF (Figure 4A, 4B). The alteration of action potential found in ventricular myocytes possibly due to ionic mechanisms.

\section{Metabolic analysis}

Metabolic changes in PM2.5-exposed mice serum and organs (heart, liver, lung, and kidney) extracts were analyzed by using UPLC-Q-TOF MS system and its software Progenesis QI (Waters). First, we used Principal Component Analysis (PCA) to investigate grouping of metabolites among different groups (Figure 5). In order to identify potential compounds as biomarkers, we choose top 5 metabolites via Fragmentation Score. The results showed that 1) top 5 metabolites in serum are Benzo(a) pyrene, Niacinamide, Phenanthrene, Acenaphthene, and Citrate; 2) top 5 metabolites in heart are Hippurate, Arginine, Ornithine, Neryl rhamnosyl-glucoside, N-(1-Deoxy-1-fructosyl) alanine; 3) top 5 metabolites in lung are Lysophosphatidylcholine

A
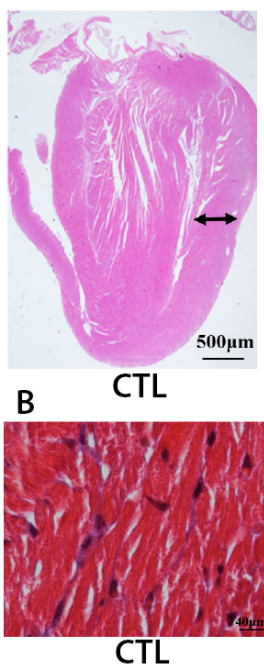
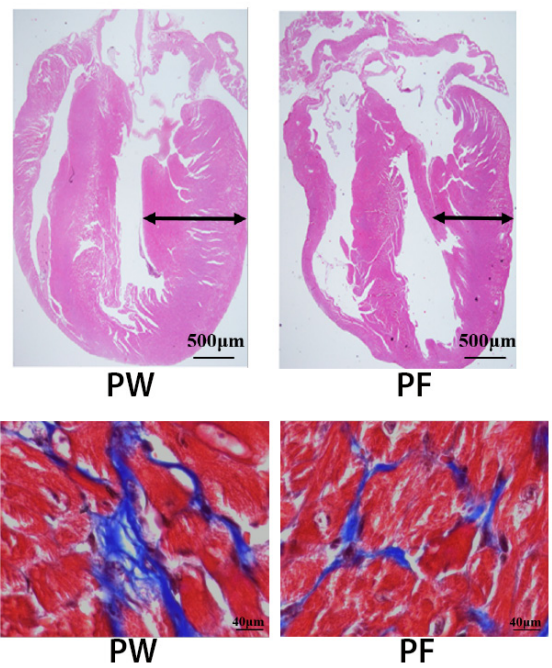

Figure 2: H\&E staining for cardiac morphology (A) and Masson's trichrome staining for cardiac fibrosis (B).
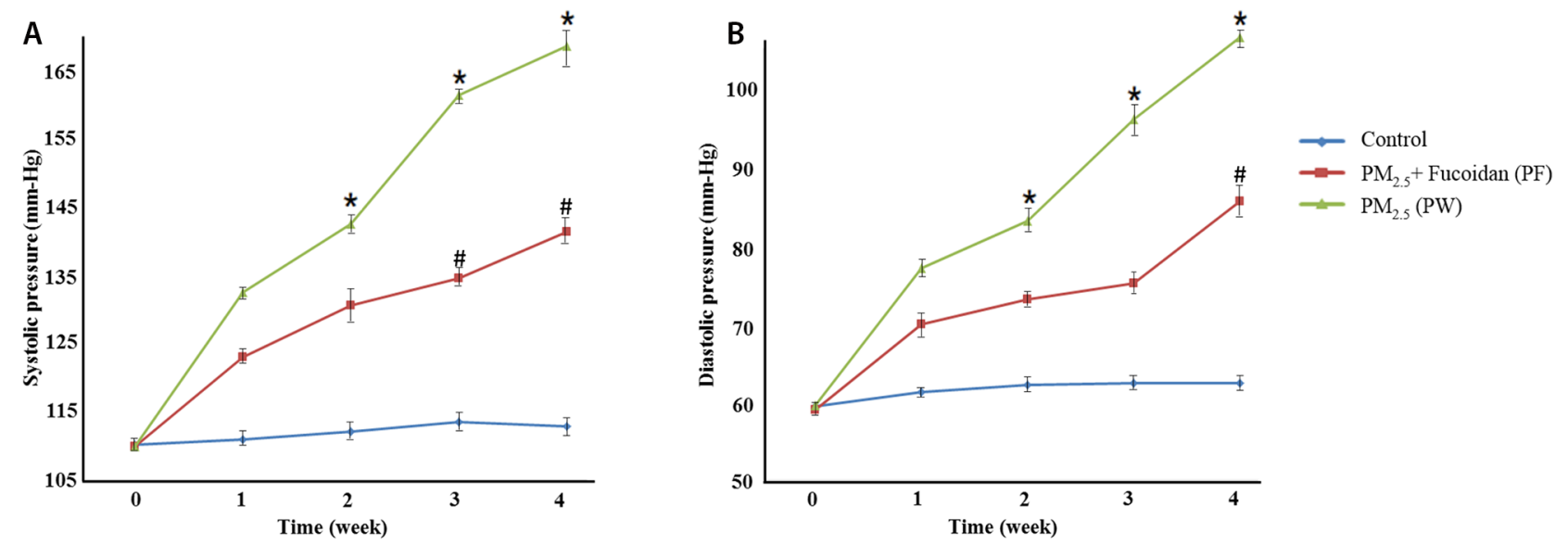

Figure 3: Systolic pressure measurements for 4 weeks (A). Compared with PM2.5 exposed mice and control group, mice with supplemented fucoidan had a significant decrease in systolic and blood pressure. Diastolic pressure measurements for 4 weeks (B). Compared with PM2.5 exposed mice and control group, mice with supplemented fucoidan had a significant decrease in diastolic blood pressure as well. ${ }^{*}$ for comparison with Control; \# for comparison with PM2.5, the values were mean $\pm \mathrm{SD}, \mathrm{P}<0.05$. 
Table 1: Top 5 metabolites in mice serum, heart, lung, liver, and kidney after PM2.5-exposed

\begin{tabular}{|c|c|c|c|c|c|}
\hline \multicolumn{2}{|c|}{ Metabolites in serum } & \multicolumn{2}{|c|}{ Metabolites in heart } & \multicolumn{2}{|l|}{ Metabolites in lung } \\
\hline Compound Name & Fold Change & Compound Name & Fold Change & Compound Name & Fold Change \\
\hline Benzo(a) pyrene & 2.8 & Hippurate & 4.2 & Lysophosphatidylcholine (24:0) & 8 \\
\hline Niacinamide & 2.2 & Arginine & 2.6 & Sphinganine $(17: 0)$ & 1.8 \\
\hline Phenanthrene & 3.1 & Ornithine & 2.1 & Sulfatide & 10.3 \\
\hline Acenaphthene & 4 & $\begin{array}{l}\text { Nerylrhamnosyl- } \\
\text { glucoside }\end{array}$ & 3.3 & Glucosylceramide (24:1) & 1.9 \\
\hline Citrate & 3.7 & $\begin{array}{l}\mathrm{N}-(1-\mathrm{Deoxy}-1- \\
\text { fructosyl) alanine }\end{array}$ & 28.6 & Sulfatide (12:0) & 3.4 \\
\hline \multicolumn{3}{|c|}{ Metabolites in liver } & \multicolumn{3}{|c|}{ Metabolites in kidney } \\
\hline \multicolumn{2}{|l|}{ Compound Name } & Fold Change & \multicolumn{2}{|r|}{ Compound Name } & Fold Change \\
\hline \multicolumn{2}{|c|}{ N (6) -(1,2-dicarboxyethyl) AMP } & 2.8 & \multicolumn{2}{|r|}{ Hypoxanthine } & 2.5 \\
\hline \multicolumn{2}{|l|}{ Glycyl-Tryptophan } & 2.5 & \multicolumn{2}{|r|}{ Hippurate } & 18 \\
\hline \multicolumn{2}{|c|}{ Adenosine $2^{\prime}$-phosphate } & 6.1 & \multicolumn{2}{|r|}{ 2,3-Octanedione } & 2 \\
\hline \multicolumn{2}{|l|}{ TG(18:0/18:0/18:0) } & 3.1 & \multicolumn{2}{|r|}{ Phenylglyoxylic acid } & 3.7 \\
\hline \multicolumn{2}{|c|}{$\begin{array}{l}\text { 4'-MeSO2-polychlorinated } \\
\text { biphenyls } 87\end{array}$} & 12 & \multicolumn{2}{|r|}{ Allantoin } & 2.2 \\
\hline
\end{tabular}

All metabolites were sorting via fold change.

(24:0), Sphinganine (17:0), Sulfatide, Glucosylceramide (24:1), Sulfatide (12:0); 4) top 5 metabolites in liver are N (6) -(1,2-dicarboxyethyl) AMP, Glycyl-Tryptophan, Adenosine 2'-phosphate, TG(18:0/18:0/18:0), 4'-MeSO2-polychlorinated biphenyls 87 ; 5) top 5 metabolites in kidney are Hypoxanthine, Hippurate, 3-Octanedione, Phenylglyoxylic acid, Allantoin. (Table 1).

\section{SOS1, CREB and GSK3b protein level were elevated under PM2.5 exposure}

In order to figure out potential mechanism of how fucoidan ameliorated cardiac function of PM2.5 exposed mice, proteins expression level of SOS1, CREB, GRB2, GSK3b were investigated. Western blot data shown SOS1, CREB and GSK3b expression levels were increased while GRB2 were not changed under PM2.5 exposure (Figure 6). CREB level was reduced under fucoidan treatment while GSK3b, SOS1, and GRB2 were not changed.

\section{Metacore analysis for potential pathways involve in cardiac hypertrophy}

After metabolites identification, these small molecules were mapped into their related signal pathways by Metacore
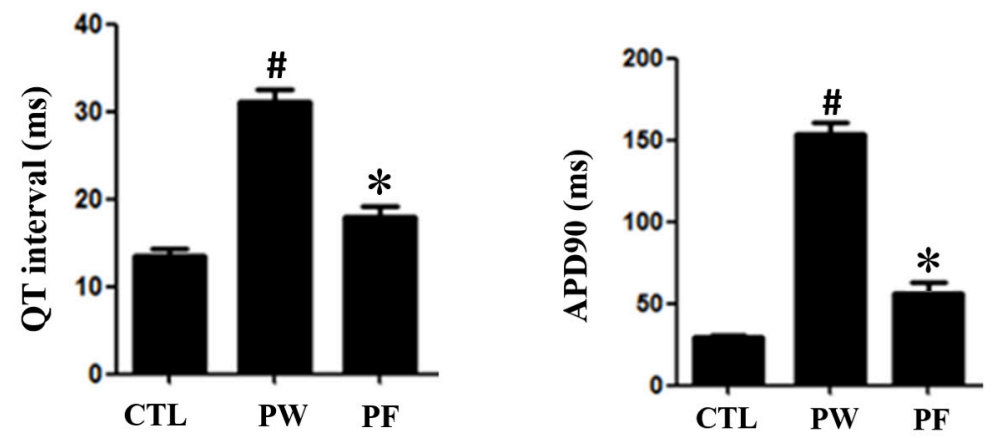

Figure 4: ECG of each group. QT interaval in PM2.5 exposure mice had prolongation. However, after fucoidan treatment, ECG prologation significiantly decreased ("for comparison with Control; \# for comparison with $\mathrm{PM} 2.5$, the values were mean $\pm \mathrm{SD}, \mathrm{P}<0.05$ ). Action potential of mice ventricular myocyte. The plateau phase had the same trend to ECG ("for comparison with Control; \# for comparison with $\mathrm{PM} 2.5$, the values were mean $\pm \mathrm{SD}, \mathrm{P}<0.05$ ). 
network database (GeneGo, MI, USA). The results form Metacore shown that "Muscle contraction_Regulation of eNOS activity in endothelial cells" pathway and "Muscle contraction Nitric oxide signaling in the cardiovascular system" network were likely involved in PM2.5 exposure (Figures 7-9) [21]. Significant difference level was set at $\mathrm{p}$-value $<0.05$.

Nitric oxide (NO) is known to involve in catalyzing for the conversion of L-arginine to L-citrulline. NO
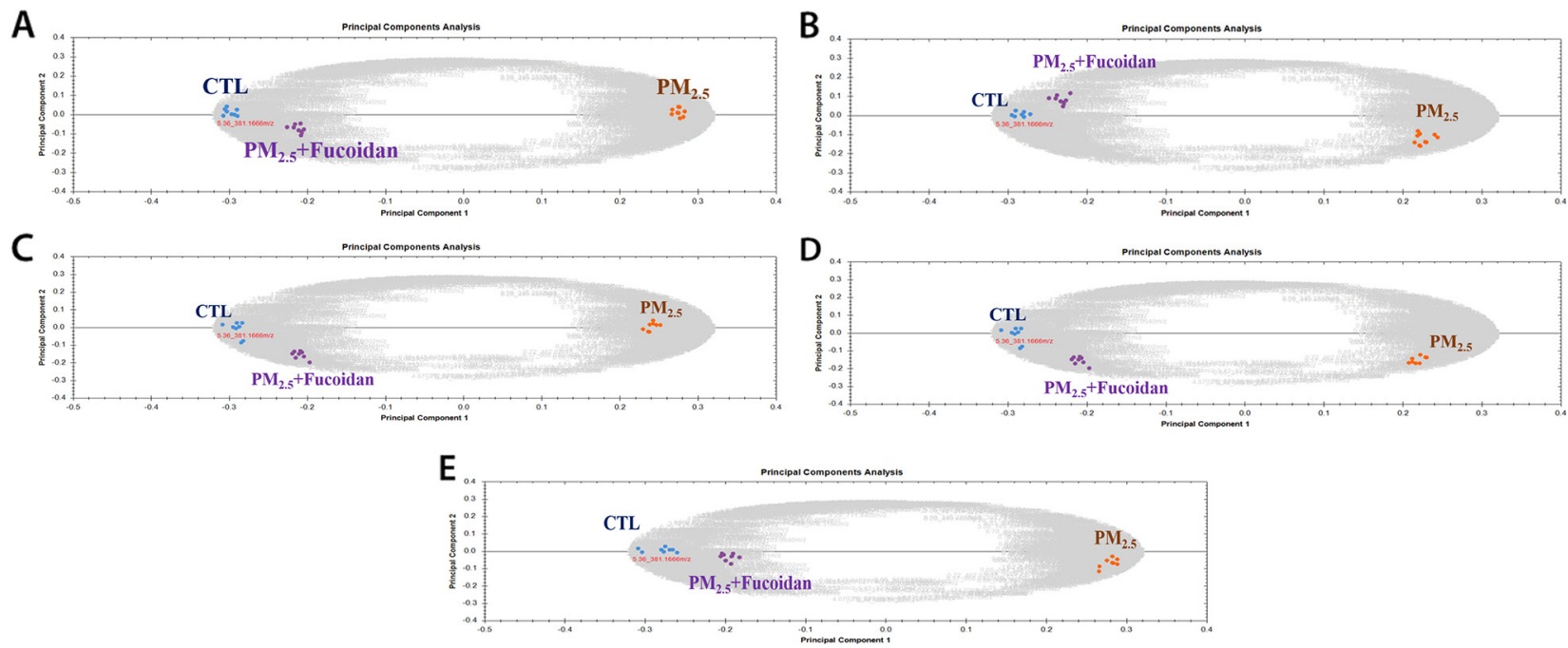

Figure 5: Principle component analysis of metabolites from three groups. (A) Metabolites from serum sample, (B) Metabolites from heart sample, (C) Metabolites from kidney sample, (D) Metabolites from lung sample, (E) Metabolites from liver sample.

A
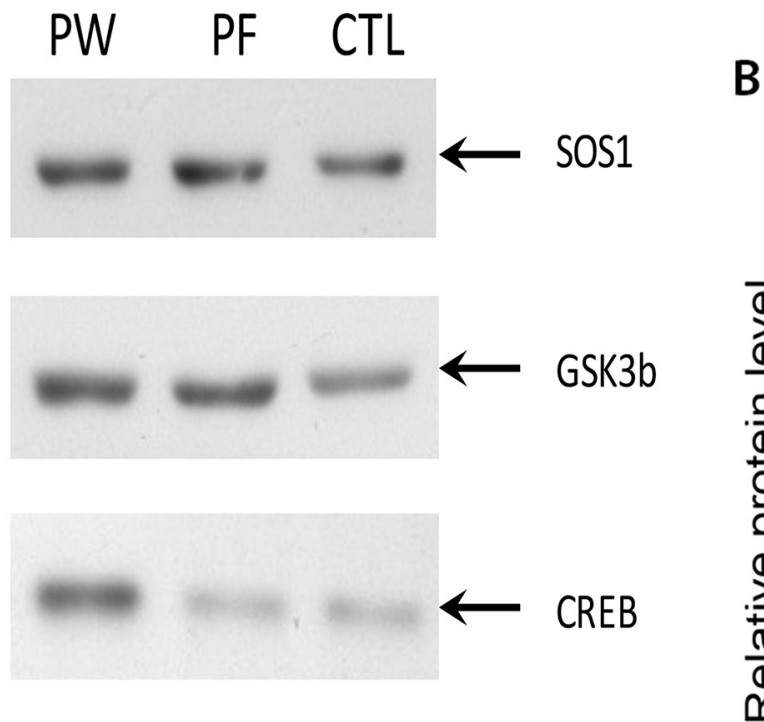

\section{B}
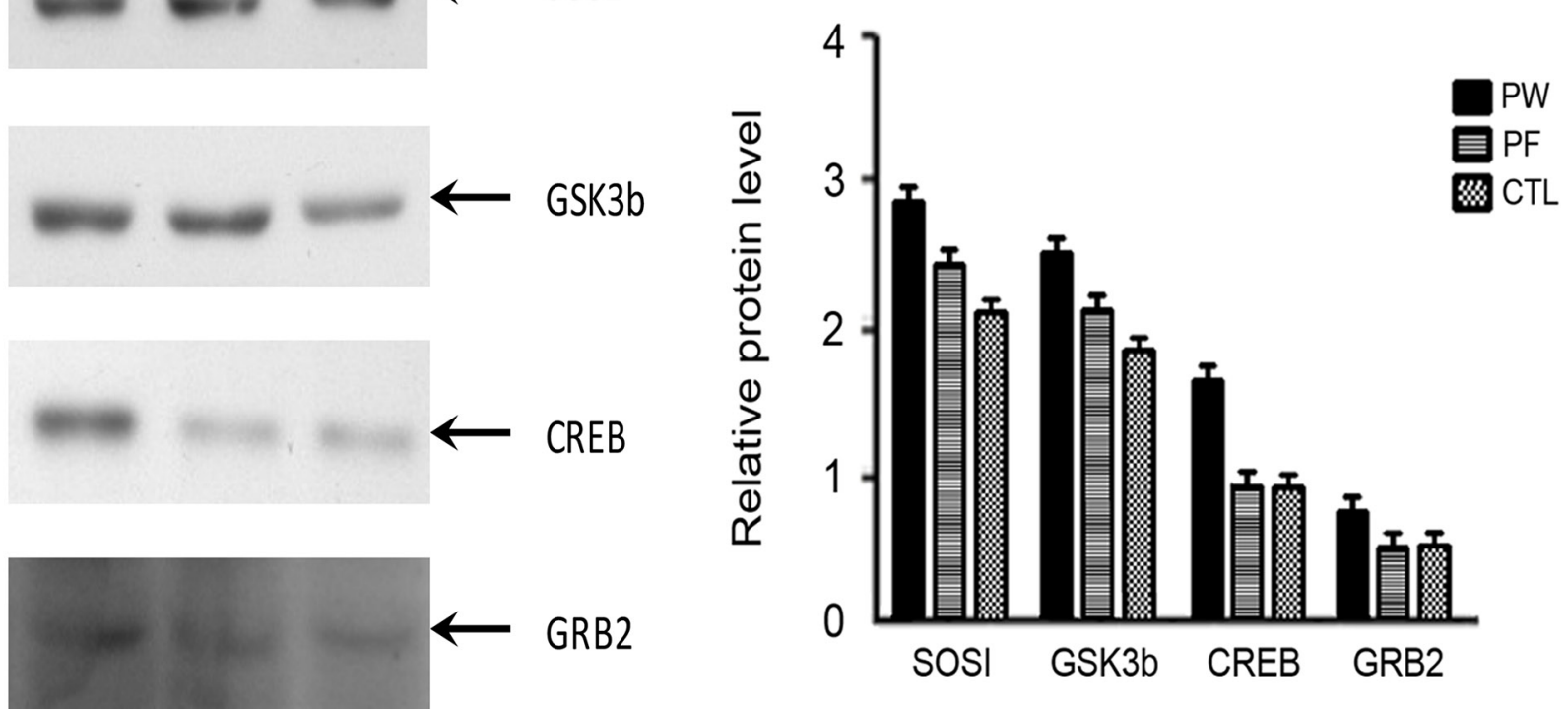

Figure 6: Western blot results of 4 proteins namely SOS1, GSK3b, CREB and GRB2 from three groups (A). Quantification bar chart of SOS1, GSK3b, CREB and GRB2 protein level (B). CTL: control, PW: PM2.5 exposed subjects treated with normal water, PF: PM2.5 exposed subjected treated with fucoidan) treated with normal water, PF: PM2.5 exposed subjected treated with fucoidan. 
belongs to family of nitric oxide synthases (NOSs) [21]. There are three manin type of NOSs namely endothelial NOS (eNOS), neuronal NOS (nNOS) and inducible NOS (iNOS) which have different functions. Each of them only expressed in specific types of tissue. For instance, eNOS expressed dominantly in endothelial cells and cardiac myocytes. The nNOS mainly expressed in brain and skeletal muscle as well as cardiomyocytes. The iNOS expressed in a wider range of tissue namely endothelial cells, cardiomyocytes, and inflammatory cells. Under

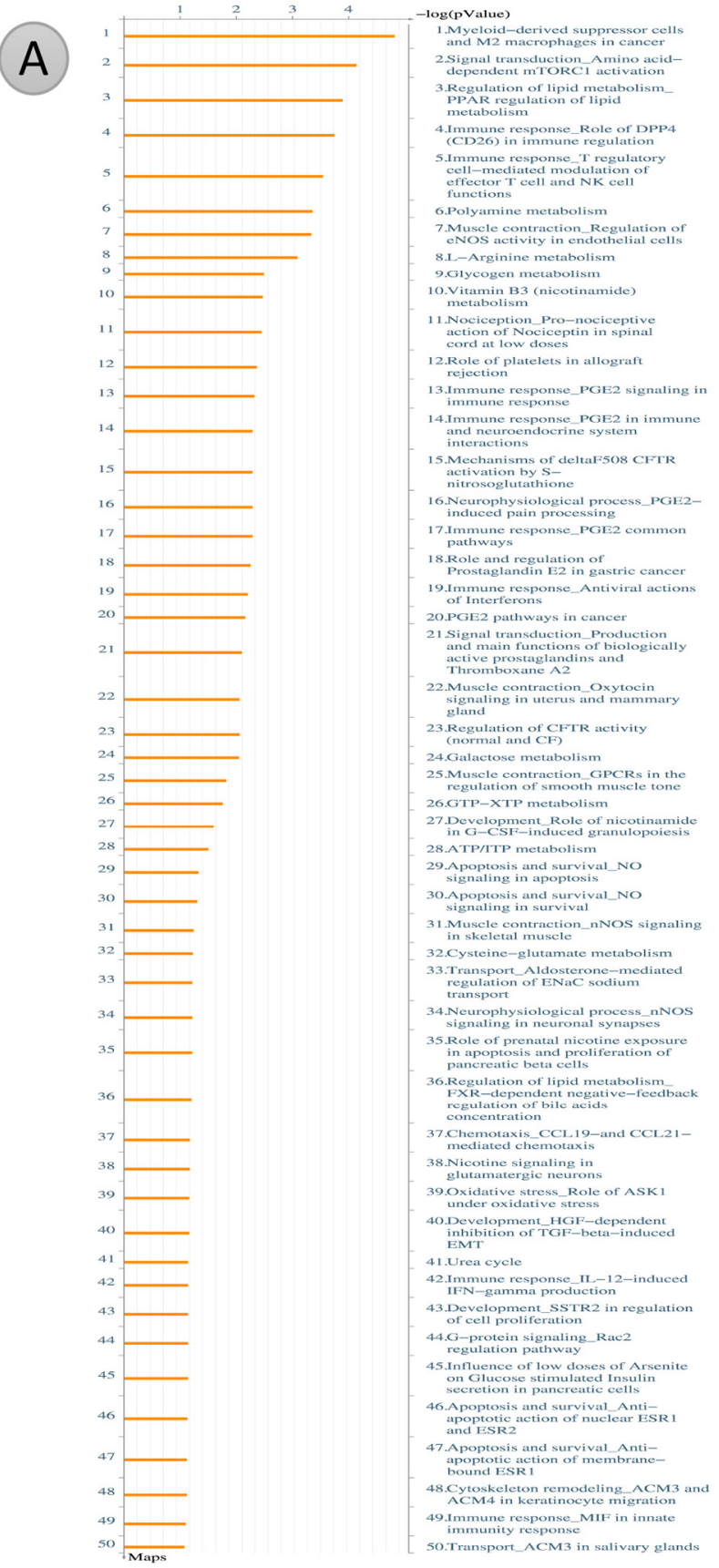

some certain circumstance such pathological condition, eNOS and $\mathrm{n}$ NOS can be consider as regulated expression [21]. These two type of NOSs are $\mathrm{Ca}(2+) / C a l m o d u l i n-$ dependent enzymes that inducible by stimulus- or agonist. In endothelial cells, eNOS generates NO which in turn takes part in angiogenesis and normal blood pressure balancing. Relaxation event of vessel wall is a result of No induced by Bradykinin, Endothelin-1 and VEGF-A in endothelial cell. The activity of eNOS in under control of various cell levels transcription, post-transcriptional

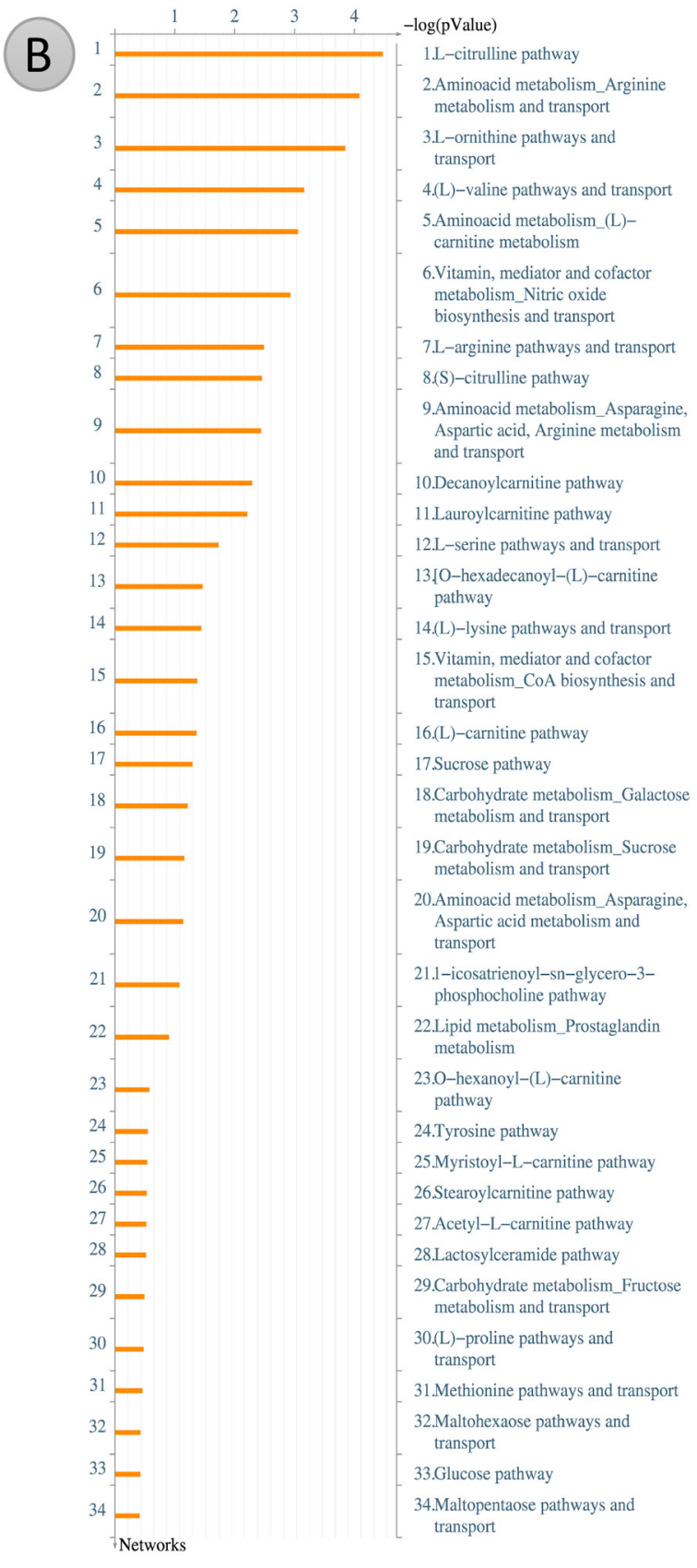

Figure 7: Metacore analysis for potential pathways involve in cardiac hypertrophy. (A) Pathway Maps analysis. (B) Metabolic Networks analysis. 
and post-translational modifications, such as acylation and phosphorylation, protein-protein interactions, and subcellular localization. Both oxygen consumption and timing for relaxation stage in myocardium are affected by the releases of NO from the coronary endothelium in paracrine mode. In addition, The modulation of basal inotropy and cardiac muscle relaxation are affected by NO produced in the cardiomyocyte in autocrine mode. There are two main group of signals namely neurotransmitters and hormones control the force and frequency of myocardial contraction. Neurotransmitters such as (L)-Noradrenaline and (L)-Adrenalineare released by the sympathetic nerves in the heart and adrenal glands released into the circulation, respectively. These signals rise myocardial contractility of the heart. To reduce the contractility of heart muscle, parasympathetic nerves releases Acetylcholine which binds to the receptor named muscarinic cholinergic. NO is the regulator of these two pathways. NO is generated endogenously within cardiac muscle cells. NO also can affect to various ion channels in the heart. For instance, NO level can modulateL-type $\mathrm{Ca}(\mathrm{II})$ channel activity. In some cases, cGMP-dependent Protein kinase G and cGMP-regulated phosphodiesterases can alsomediate NO function [21].

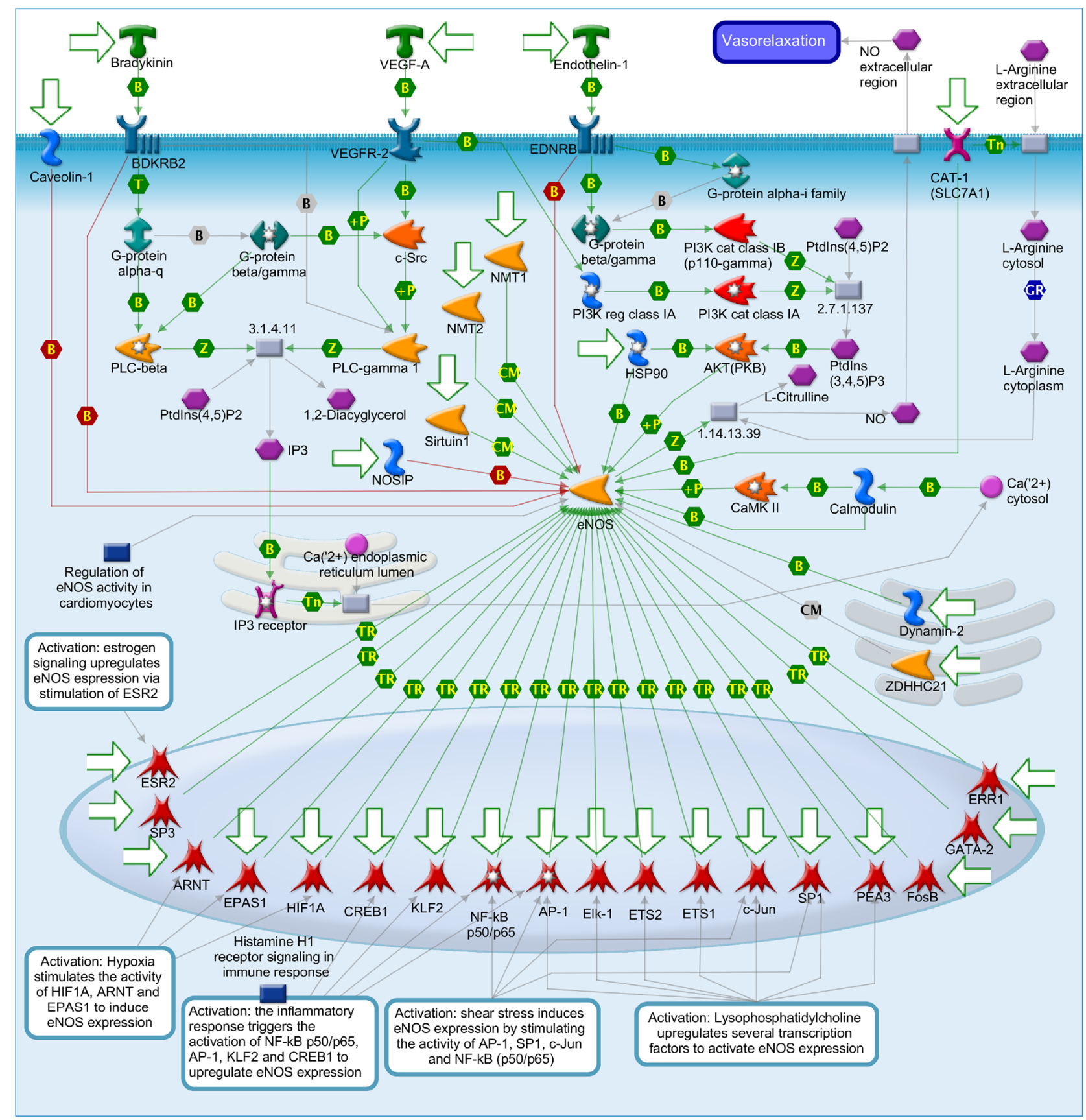

Figure 8: Muscle contraction_Regulation of eNOS activity in endothelial cells. 
The bioinformatics results suggest that PM2.5 and fucoidan are supposed to participate in the cardiac hypertrophy pathway via eNOS and CREB related signaling (Figures 7-9). Until now, no holistic approach has been used to demonstrate the potential signal pathways involving in PM2.5 exposure and fucoidan effects. Therefore, our work is the first paper to reveal the potential signal pathway may involve in PM2.5 exposure and use fucoidan as bioactive compound to enhance and/or recover the overall cardiac function of exposed subjects. The present investigation provides potential target genes or protein in PM2.5 exposure and fucoidan effects for prospective researches.

\section{DISCUSSION}

In the present study, cardioprotective effects of fucoidan has been demonstrate with various examinations. Fucoidan could likely reduce the cardiac hypertrophy, cardiac fibrosis, long QT interval in PM2.5 exposed mice. Cardiac abnormality by PM2.5 exposure might due to metabolic disorder in numerous metabolites as well as alteration in gene expression such as SOS1, CREB and GSK3b.
Long QT interval was previously proved associated atherosclerosis [22, 23]. QT interval has been documented as a reliable predictor of ventricular arrhythmias [24]. Moreover, Long QT interval, cardiac hypertrophy and cardiac sudden death were highly associated [25]. In the present findings, we found that both ventricular hypertrophy and QT prolongation presented inPM2.5 exposed subjects, which could suggest that PM2.5exposed mice are more likely facing with cardiac sudden death. However, cardiac function of mice with PM2.5 exposure could be recovered to some extend such as QT recovery and cardiac tissue enhancement, decrease in fibrosis percentage by treatment with fucoidan.

Fucoidan is reported with anti-oxidative and antiinflammatory properties [26-30]. Recently, accumulation studies focused on the low molecular weight fucoidan due to its higher biological activities [26, 31-34]. Fucoidan also were used to myocardial infarction in rats model, and it shown cardioprotective effect by recovering the damage region induced by isoproterenol [20]. Fucoidan can protect the damage caused by myocardial ischemiareperfusion [35].

Glycogen synthase kinase-3 (GSK-3) plays vital role in cardiac hypertrophy. In previous study,

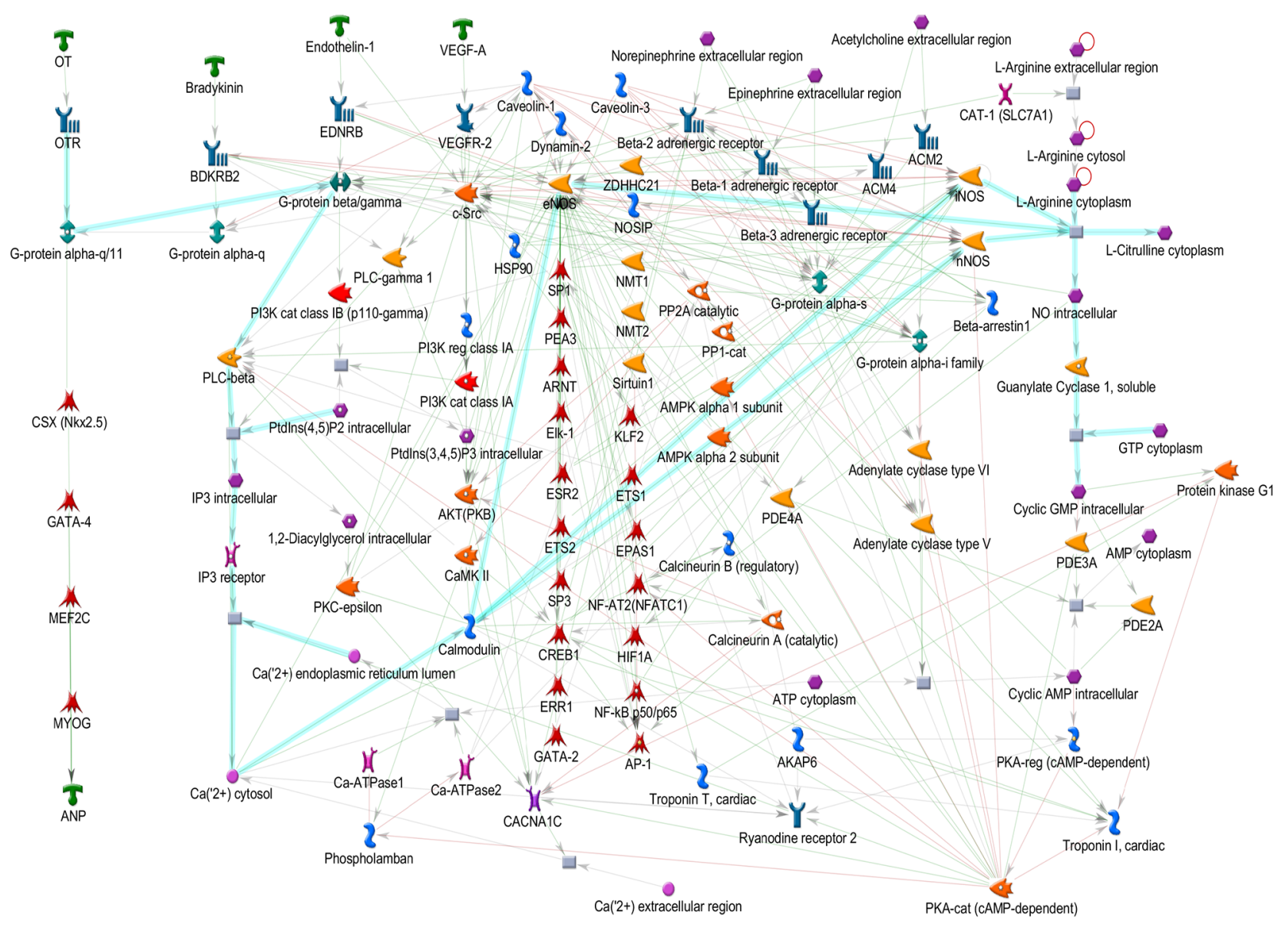

Figure 9: Muscle contraction_Nitric oxide signaling in the cardiovascular system. 
2,5-dimethylcelecoxib (DM-celecoxib) can activate GSK$3 \alpha$ and $\beta$ by inhibiting Akt, to prevent left ventricular hypertrophy and fibrosis [36]. CREB is a well know protein that involves in many crucial pathways related to cardiac fibrosis [37, 38], cardiac hypertrophy [39, 40]. Both GSK $3 \beta$ and CREB protein expression level were up regulated in $\mathrm{PW}$ group relative to control group. After fucoidan treatment, CREB level was reduced while GSK3b was not significantly changed. This result suggests that CREB protein may be a target of fucoidan molecule.

Previous studies claimed that PM2.5 caused damage to zebrafish embryo such as skin aging and oxidative stress [41]. Besides, PM2.5 exposure is associated with metabolic diseases such as insulin resistance [42]. In addition, PM2.5 affects to lipoproteins and causes atherosclerosis and embryonic toxicity as well [42, 43]. PM2.5 exposure also results in systemic vascular failure by NADPH oxidase and TLR4 pathways, which cause systemic inflammation. In addition, PM2.5 is also suggested to disturb the reduced-oxidized balance and lead to vasoconstrictive responses [43]. According to our results, we could establish PM2.5-induced high blood pressure mice animal, which can be used as one animal model to identify whether some natural compounds have reversed effects on cardiac dysfunction.

PM2.5 exposure and cardiac abnormality and complications have been reported previously [44]. A $10 \mu \mathrm{g} / \mathrm{m}^{3}$ increase of PM2.5 level within $24 \mathrm{~h}$ will increase about $1.0 \%$ of the relative risk (RR) of daily cardiovascular mortality [45]. According to our study, cardiac structural remodeling and dysfunction caused by PM2.5 were recorded. Besides, metabolomics was used as the main approach to identify component of PM2.5 which will highly impact to cardiac function, and pathway they patriciate. First, we found benzo[a]pyrene (B[a]P), a wellknown carcinogenic polycyclic aromatic hydrocarbon (pAH), has the highest level in PM2.5 exposure mice serum, may cause DNA damage in lung adenocarcinoma CL-3 cells. Based on related research report, $10 \mathrm{mM}$ $\mathrm{B}[\mathrm{a}] \mathrm{P}$-treated CL-3 cells have $\mathrm{G} 2 / \mathrm{M}$ arrestwhich was independent with $\mathrm{p} 53$ pathway. In addition to $\mathrm{B}[\mathrm{a}] \mathrm{P}$, we found out other 2 compounds, acenaphthene and phenanthrene, which belong to PAH group as well.

B(a) P was reported to cause defect of cardiovascular development by aryl hydrocarbon receptor or up regulated of rbp4 and may results in cardiac hypertrophy by activating TLR4/MyD88 signal pathway [46-48].

Our finding demonstrated that LMW could enhance the cardiac status of mice with PM2.5 exposures by rescued QT interval prolongation, action potential and cardiac hypertrophy, and cardiac fibrosis decline. The in vitro and in vivo toxicology of PM2.5 and its mode of action were not thoroughly investigated. The elements of PM2.5 mixture varies from one to another area. Therefore, it is important to investigate the individual and combinatory impact of PM2.5 compounds.

\section{MATERIALS AND METHODS}

\section{Animal model}

Total 24 C57BL/6J mice, 8 weeks old, were purchased form (BioLasco company, Taiwan. Mice were housed in animal house in standard conditions with light/ dark period of $12 \mathrm{~h}$ each. Food and water were always available for animals. Three groups of animals, each of 8 , according to experimental conditions were obtained. They were control group (Ctrl) with no PM2.5 exposure or fucoidan (Hi-Q Oligo-Fucoidans ${ }^{\circledR}$ ) treatment, PM2.5 exposed group without treatment (PW), and PM2.5 exposed group with $300 \mathrm{mg} / \mathrm{kg}$ fucoidan administration daily in 28 days (PF). The study procedure with animal was approved by IACUC, Chinese Culture University, Taiwan, ROC.

\section{CAPs PM 2.5 preparation and exposure to animal}

The BGI PQ200-FRM Sampler machine was used for PM2.5 collection at Taipei Main Station 3 hours per day from November to December, 2016. Mice were exposed to PM2.5 solution $\left(100 \mu \mathrm{g} / \mathrm{m}^{3}\right)$, which is the collected PM2.5 powder in $\mathrm{ddH}_{2} \mathrm{O}$, in a chamber. The flow rate of PM2.5 solution is $3.5-4.0 \mathrm{~L} / \mathrm{min}$, and the solution is atomized with the mixture of air. All the mice exposed to PM2.5 consecutive 28 days ( $6 \mathrm{~h} /$ day) and every 5 days took a break of 2 days. ECG and blood pressure were measured every week. After 28 days mice were all sacrificed.

\section{CAPs PM 2.5 composition analysis}

We used UPLC-Xevo G2-S Q-Tof (Waters, USA) system and iCAP -Q ICP-MS (Thermo Fisher Scientific, Waltham, MA, USA)to analyze components of PM2.5 mixture.

\section{Blood pressure measurement}

BP2000 Visitech Systems was used for measure blood pressure from mice tail by an emitter assembly, which contains a red LED to illuminate the tail. Before started, all the mice should put into the Specimen platform, which holds the animals, and has the sensor(s) and occlusion cuff(s). Blood pressure of each mouse was detected for 10 times every weekend. All the data recorded by the BP-2000 Analysis software.

\section{ECG recording}

ECG measurement was done to record the QT interval of experimental mice. ECG system consist of 3 leads vector connected to the signal recording and application system (PowerLab/4SP analog-to-digital converter, AD Instruments, Colorado Springs, CO). A mixture of $2 \%$ isoflurane and compressed oxygen was 
used for anesthesia with flow rate at $2 \mathrm{~L} / \mathrm{min}[49,50]$. Data of each group were derived from 8 mice.

\section{Action potential recording}

The method was previously described in detail [51]. In brief, action potential from ventricular isolated cardiomyocyte from mice was recorded in Tyrode and pipette solutions. The patch clamp setup was done with bright-field and fluorescent light sources, and CCD camera.

\section{Histology (H\&E staining)}

Hematoxylin and eosin staining method was described previously by Phan et al. [52]. Briefly, the whole heart was removed and washed twice in PBS to remove the blood as much as possible. It was then fixed in $4 \%$ paraformaldehyde (PFA) at $25^{\circ} \mathrm{C}$ overnight. PFA section then exchanged with $70 \%$ Ethanol, fixed in paraffin and cut at $2.5 \mathrm{~mm}$. Paraffin sections were rehydrated and stained with hematoxylin and eosin.

\section{Masson trichrome staining}

Masson trichrome staining was done as our previous publication [52]. Masson trichrome staining was done as our previous publication [28]. Briefly, alcohol (100\% alcohol, $95 \%$ alcohol $70 \%$ alcohol) was used to de-paraffinize and rehydrate cardiac tissue. To improve staining quality, Bouin's solution was applied for 15 minutes at $56^{\circ} \mathrm{C}$ and rinse under tap water for $5-10$. Next, immerged in Weigert's iron hematoxylin solution 10 minutes then wash with PBS buffer 5 minutes. Afterward, stained with Biebrich scarlet-acid fuchsin solution for 5 minutes, then washed in distilled water. Then sections underwent series of differentiation, dehydration in $75 \%$ and $90 \%$ alcoho and rinsing in tap water. Finally, sections were cleared in xylene and mounted.

\section{Western blot assay}

This assay was done as previously described document [52]. Briefly, the cardiac tissue was isolated and removed all fat and connective tissue. Tissue homogenization was done with lysis buffer (Thermo Fisher Scientific Inc.) on ice. Centrifugation was used to remove large tissue and nuclear fragments at $7000 \mathrm{~g}, 4^{\circ} \mathrm{C}$ for 10 minutes then collected supernatant. NANOVUE PLUS ${ }^{\mathrm{TM}}$ SPECTROPHOTOMETER (Harvard Bioscience, Inc.) was used for protein concentration measurement. Total protein $(40 \mu \mathrm{g})$ was loaded to $10 \%$ SDS gel and run for $1 \mathrm{~h}$ at $100 \mathrm{~mA}$. Afterward, a polyvinylidine fluoride (PVDF) membrane was used to transfer protein bands on ice in $1 \mathrm{~h}$ at $100 \mathrm{~mA}$. Blocking of membrane was done with $10 \%$ non-fat dry milk
(Bio-rad) and then incubated overnight with primary antibodies diluted in 5\% milk. Primary antibody as followed: polyclonal antibodies against Phospho-GRB2 antibody [Y237] (ab32037) (1:1000, ABCAM), PhosphoSOS1 (ab64595) (1:1000, ABCAM), phosphor-GSK3 beta [Y216] (ab75745) (1:1000, ABCAM), phosphorCREB [E113] (ab32096) (1:1000, ABCAM) and GAPDH (1:1000, ABCAM). Afterward, secondary antibodies, horseradish peroxidase (HRP) $(1: 10000)$, was used to incubate with the membranes at room temperature. The membrane was finally read by C-DiGit ${ }^{\circledR}$ Blot Scanner (LI-COR Biosciences).

\section{Metabolomic analysis}

\section{Sample preparation}

Upon sacrifice, serum was collected. The whole heart was acquired rapidly and washed with PBS twice for blood removal and freeze in liquid nitrogen. Liver, lung, and kidney tissue were also collected and immerged in liquid nitrogen. All organs were then stored at $-80^{\circ} \mathrm{C}$ for later experiment.

To prepare serum for mass spectrometry analysis, protein precipitationmust be done with cold acetonitrile (ACN). For sample preparation of tissue from organs, 100 $\mu l$ RIPA buffer with $1 \mu l$ phosphatase inhibitor was added to $10 \mathrm{mg}$ tissue of each organ and ultra-sonicated for 1 min. $400 \mu$ lof ACN was added into $100 \mu \mathrm{l}$ of homogenate and centrifugedat $12,000 \mathrm{~g}$ for $15 \mathrm{~min}$, at $4^{\circ} \mathrm{C}$. The supernatant was obtained andfiltered with $0.45 \mu \mathrm{m}$ filter for mass spetrometry analysis.

\section{LC-MS/MS analysis}

For metabolomics analysis, UPLC-Q-TOF MS system (Waters) was employed. Samples were injected to Acquity UPLC BEH C18 column $(2.1 \times 50 \mathrm{~mm}, 1.7$ $\mu \mathrm{m}$; Waters) by $0.1 \%$ formic acid (FA) in water. Elution process was done with gradient of $0.1 \% \mathrm{FA}$ in CAN at flow rate of $0.2 \mathrm{~mL} / \mathrm{min}$ for $10 \mathrm{~min}$ for each sample. Electrospray ionization (ESI) positive mode was chosen for Q-TOF. Metabolite mass per charge ratio was set from 100 to 1,500. Finally, MassLynx software (Waters) was employed for mass accuracy processing and composition of the precursor and fragment ions analysis.

\section{LC-MS/MS data processing}

Raw LC/MS data extracted from MassLynx software (Waters) was processed Progenesis QI software for Metabolite identification. Theoretical fragmentation analysis was used for metabolite identification. Fragmented data were matched by default databases of Progenesis QI (Human Metabolome Database (http://www.hmdb.ca) and ChemSpider database (www.chemspider.com). Principle Component Analsysis figures was generated by Progenesis QI. 


\section{Metacore analysis for potential pathways involve in cardiac hypertrophy}

After metabolite identification, these small molecules were mapping to their related signal pathways. Accordingly, we used Metacore network database (GeneGo, MI, USA) pathways of these compounds. The gene-metabolites interaction was also included in the analysis. MetaCore generated biological networks from the list of identified metabolites. Comparing the metabolites of PM2.5 exposed samples and PM2.5 unexposed samples, we uploaded the significantly metabolites into Metacore software. The results form Metacore shown that "Muscle contraction_Regulation of eNOS activity in endothelial cells" pathway and "Muscle contraction_Nitric oxide signaling in the cardiovascular system" networkwere likely involved in PM2.5 exposure (Figures 7-9). Significant difference was set at $\mathrm{p}$-value $<0.05$.

\section{Statistical analysis}

One-way analysis of variance (ANOVA) for statistical different between group was done by SPSS version 20. Data were displayed in mean \pm standard deviation. $P$-value $<0.05$ means significant different.

\section{Abbreviations}

Relative Risk (RR)

Glycogen Synthase Kinase-3 (GSK-3)

2,5-Dimethylcelecoxib (DM-Celecoxib)

Electrospray Ionization (ESI)

Acetonitrile (ACN)

Polyvinylidine Fluoride (PVDF)

Paraformaldehyde (PFA)

Control Group (Ctrl)

PM2.5 Exposed Group Without Treatment (PW)

PM2.5 Exposed Group With $300 \mathrm{Mg} / \mathrm{Kg}$ Fucoidan

Administration Daily In 28 Days (PF)

Concentrated Ambient Particles (Caps)

Particle Matter (PM)

Low Molecular Weight (LMW).

\section{Author contributions}

Experimental design: KLL, YCL; Doing experiment: KLL; Data collection: KLL; Writing manuscript: KLL, YCL; Manuscript proofreading: KKL, YCL.

\section{DECLARATIONS}

Ethics approval and consent to participate: Ethic procedute was approved by IACUC, Chinese Culture University, Taiwan. Consent to participate: Not applicable

Consent for publication: Not applicable

Availability of data and material: All data are available upon request.

\section{ACKNOWLEDGMENTS}

We thank to Taiwan HI-Q MARINE BIOTECH INTERNATIONAL LTD., Taipei City 211, Taiwan for nature compound support.

\section{CONFLICTS OF INTEREST}

Authors declare no conflicts of interest in this study.

\section{FUNDING}

We thanks to Precision Instrument Development Center, College of Agriculture, Chinese Culture University, Taipei, Taiwan for machine support. We thanks to National Science Council of the Executive Yuan, Taiwan (NSC 104-2320-B-034-003, NSC 105-2320-B034-001 to Yen-Chang Lin) and Ministry of Science and Technology (MOST 106-2320-B-034-001 to Yen-Chang Lin) for financial support. There is no role of funders in composing this manuscript.

\section{REFERENCES}

1. Frumkin H. Understanding the health effects of components of the particulate matter mix: progress and next steps. Cambridge, MA: Health Effects Institute. 2002.

2. Azarmi F, Kumar P, Marsh D, Fuller G. Assessment of the long-term impacts of PM 10 and PM 2.5 particles from construction works on surrounding areas. Environ Sci Process Impacts. 2016; 18:208-21.

3. Gugamsetty B, Wei H, Liu CN, Awasthi A, Hsu SC, Tsai CJ, Roam GD, Wu YC, Chen CF. Source characterization and apportionment of PM10, PM2. 5 and PM0. 1 by using positive matrix factorization. Aerosol Air Qual Res. 2012; $12: 476-91$

4. Lepeule J, Laden F, Dockery D, Schwartz J. Chronic exposure to fine particles and mortality: an extended follow-up of the Harvard Six Cities study from 1974 to 2009. Environ Health Perspect. 2012; 120:965-70. https://doi.org/10.1289/ehp.1104660.

5. Godleski JJ, Verrier RL, Koutrakis P, Catalano P, Coull B, Reinisch U, Lovett EG, Lawrence J, Murthy GG, Wolfson JM, Clarke RW, Nearing BD, Killingsworth C. Mechanisms of morbidity and mortality from exposure to ambient air particles. Res Rep Health Eff Inst. 2000:5-88; discussion 9-103.

6. Kylin H. Zur Biochemie der Meeresalgen. [Article in German]. Hoppe Seylers Z Physiol Chem. 1913; 83:171-97.

7. Ponce NM, Pujol CA, Damonte EB, Flores ML, Stortz CA. Fucoidans from the brown seaweed Adenocystis utricularis: extraction methods, antiviral activity and structural studies. Carbohydr Res. 2003; 338:153-65. 
8. Zhuang $\mathrm{C}$, Itoh $\mathrm{H}$, Mizuno $\mathrm{T}$, Ito $\mathrm{H}$. Antitumor active fucoidan from the brown seaweed, umitoranoo (Sargassum thunbergii). Biosci Biotechnol Biochem. 1995; 59:563-7. https://doi.org/10.1271/bbb.59.563.

9. Fitton JH. Therapies from fucoidan; multifunctional marine polymers. Mar Drugs. 2011; 9:1731-60. https://doi.org/10.3390/md9101731.

10. Hsu HY, Lin TY, Hwang PA, Chen RH, Tsao SM, Hsu J. Fucoidan induces changes in the epithelial-mesenchymal transition and decreases metastasis by enhancing ubiquitindependent TGF $\beta$ receptor degradation in breast cancer. Carcinogenesis. 2013; 34:874-84.

11. Tengdelius $\mathrm{ME}$, Lee CJ, Grenegård $\mathrm{M}$, Griffith $\mathrm{M}$, Påhlsson P, Konradsson P. Synthesis and Biological Evaluation of Fucoidan-Mimetic Glycopolymers through Cyanoxyl-Mediated Free-Radical Polymerization. Biomacromolecules. 2014; 15:2359-68.

12. Hwang PA, Chien SY, Chan YL, Lu MK, Wu CH, Kong ZL, Wu CJ. Inhibition of Lipopolysaccharide (LPS)-induced inflammatory responses by Sargassum hemiphyllum sulfated polysaccharide extract in RAW 264.7 macrophage cells. J Agric Food Chem. 2011; 59:2062-8. https://doi.org/10.1021/jf1043647.

13. Irhimeh MR, Fitton JH, Lowenthal RM. Pilot clinical study to evaluate the anticoagulant activity of fucoidan. Blood Coagul Fibrinolysis. 2009; 20:607-10. https://doi.org/10.1097/MBC.0b013e32833135fe.

14. Yang C, Chung D, Shin IS, Lee H, Kim J, Lee Y, You $\mathrm{S}$. Effects of molecular weight and hydrolysis conditions on anticancer activity of fucoidans from sporophyll of Undaria pinnatifida. Int J Biol Macromol. 2008; 43:433-7. https://doi.org/10.1016/j.ijbiomac.2008.08.006.

15. Soeda S, Sakaguchi S, Shimeno H, Nagamatsu A. Fibrinolytic and anticoagulant activities of highly sulfated fucoidan. Biochem Pharmacol. 1992; 43:1853-8.

16. Park SB, Chun KR, Kim JK, Suk K, Jung YM, Lee WH. The differential effect of high and low molecular weight fucoidans on the severity of collagen-induced arthritis in mice. Phytother Res. 2010; 24:1384-91. https://doi.org/10.1002/ptr.3140.

17. Hwang PA, Hung YL, Phan NN, Hieu BT, Chang PM, $\mathrm{Li} \mathrm{KL}$, Lin YC. The in vitro and in vivo effects of the low molecular weight fucoidan on the bone osteogenic differentiation properties. Cytotechnology. 2016; 68:134959. https://doi.org/10.1007/s10616-015-9894-5.

18. Changotade S, Korb G, Bassil J, Barroukh B, Willig C, Colliec-Jouault S, Durand P, Godeau G, Senni K. Potential effects of a low-molecular-weight fucoidan extracted from brown algae on bone biomaterial osteoconductive properties. J Biomed Mater Res A. 2008; 87:666-75.

19. Shouzhu HAO, inventors; Beijing Century Biocom Pharmaceutical Tech Co Ltd, assignee. Methods of treatment of cardiovascular and cerebrovascular diseases with fucoidan. World patent WO patent WO2008031332A1. 2008 Mar 30.
20. Thomes P, Rajendran M, Pasanban B, Rengasamy R. Cardioprotective activity of Cladosiphon okamuranus fucoidan against isoproterenol induced myocardial infarction in rats. Phytomedicine. 2010; 18:52-7. https://doi.org/10.1016/j.phymed.2010.06.006.

21. Uboldi S, Calura E, Beltrame L, Nerini IF, Marchini S, Cavalieri D, Erba E, Chiorino G, Ostano P, D’Angelo D. A systems biology approach to characterize the regulatory networks leading to trabectedin resistance in an in vitro model of myxoid liposarcoma. PLoS One. 2012; 7:e35423.

22. Ohnishi K, Yoshida H, Shigeno K, Nakamura S, Fujisawa S, Naito K, Shinjo K, Fujita Y, Matsui H, Takeshita A, Sugiyama S, Satoh H, Terada H, Ohno R. Prolongation of the QT interval and ventricular tachycardia in patients treated with arsenic trioxide for acute promyelocytic leukemia. Annals of Internal Medicine. 2000; 133:881-5.

23. Lamm SH, Engel A, Penn CA, Chen R, Feinleib M. Arsenic cancer risk confounder in southwest Taiwan data set. Environmental Health Perspectives. 2006; 114:1077-82. https://doi.org/Doi 10.1289/Ehp.8704.

24. Roden DM. Keep the QT interval: it is a reliable predictor of ventricular arrhythmias. Heart Rhythm. 2008; 5:1213.

25. Kang YJ. Cardiac hypertrophy: a risk factor for QT-prolongation and cardiac sudden death. Toxicologic Pathology. 2006; 34:58-66.

26. Wang J, Zhang Q, Zhang Z, Song H, Li P. Potential antioxidant and anticoagulant capacity of low molecular weight fucoidan fractions extracted from Laminaria japonica. International Journal of Biological Macromolecules. 2010; 46:6-12.

27. Wang J, Zhang Q, Zhang Z, Li Z. Antioxidant activity of sulfated polysaccharide fractions extracted from Laminaria japonica. International Journal of Biological Macromolecules. 2008; 42:127-32.

28. Rocha de Souza MC, Marques CT, Guerra Dore CM, Ferreira da Silva FR, Oliveira Rocha HA, Leite EL. Antioxidant activities of sulfated polysaccharides from brown and red seaweeds. Journal of Applied Phycology. 2007; 19:153-60.

29. Park HY, Han MH, Park C, Jin CY, Kim GY, Choi IW, Kim ND, Nam TJ, Kwon TK, Choi YH. Anti-inflammatory effects of fucoidan through inhibition of NF- $\kappa$ B, MAPK and Akt activation in lipopolysaccharide-induced BV2 microglia cells. Food and Chemical Toxicology. 2011; 49:1745-52.

30. Medeiros V, Queiroz K, Cardoso M, Monteiro G, Oliveira F, Chavante S, Guimaraes L, Rocha H, Leite E. Sulfated galactofucan from Lobophora variegata: anticoagulant and anti-inflammatory properties. Biochemistry (Mosc). 2008; 73:1018-24.

31. Colliec S, Boisson-vidal C, Jozefonvicz J. A low molecular weight fucoidan fraction from the brown seaweed Pelvetia canaliculata. Phytochemistry. 1994; 35:697-700. 
32. Luyt CE, Meddahi-Pellé A, Ho-Tin-Noe B, Colliec-Jouault S, Guezennec J, Louedec L, Prats H, Jacob MP, OsbornePellegrin M, Letourneur D. Low-molecular-weight fucoidan promotes therapeutic revascularization in a rat model of critical hindlimb ischemia. The Journal of Pharmacology and Experimental Therapeutics. 2003; 305:24-30.

33. Deux JF, Meddahi-Pellé A, Le Blanche AF, Feldman LJ, Colliec-Jouault S, Brée F, Boudghène F, Michel JB, Letourneur D. Low molecular weight fucoidan prevents neointimal hyperplasia in rabbit iliac artery in-stent restenosis model. Arterioscler Thromb Vasc Biol. 2002; 22:1604-9.

34. Lake AC, Vassy R, Di Benedetto M, Lavigne D, Le Visage C, Perret GY, Letourneur D. Low molecular weight fucoidan increases VEGF165-induced endothelial cell migration by enhancing VEGF165 binding to VEGFR-2 and NRP1. The Journal of Biological Chemistry. 2006; 281:37844-52.

35. Li C, Gao Y, Xing Y, Zhu H, Shen J, Tian J. Fucoidan, a sulfated polysaccharide from brown algae, against myocardial ischemia-reperfusion injury in rats via regulating the inflammation response. Food and Chemical Toxicology. 2011; 49:2090-5.

36. Fujita A, Takahashi-Yanaga F, Morimoto S, Yoshihara T, Arioka M, Igawa K, Tomooka K, Hoka S, Sasaguri T. 2, 5-Dimethylcelecoxib prevents pressure-induced left ventricular remodeling through GSK-3 activation. Hypertension Research. 2017; 40:130-139.

37. Li L, Fan D, Wang C, Wang JY, Cui XB, Wu D, Zhou Y, $\mathrm{Wu}$ LL. Angiotensin II increases periostin expression via Ras/p38 MAPK/CREB and ERK1/2/TGF- $\beta 1$ pathways in cardiac fibroblasts. Cardiovascular Research. 2011; 91:80-9.

38. Chan EC, Dusting GJ, Guo N, Peshavariya HM, Taylor CJ, Dilley R, Narumiya S, Jiang F. Prostacyclin receptor suppresses cardiac fibrosis: role of CREB phosphorylation. Journal of Molecular and Cellular Cardiology. 2010; 49:176-85.

39. Gusterson RJ, Jazrawi E, Adcock IM, Latchman DS. The transcriptional co-activators CREB-binding protein (CBP) and p300 play a critical role in cardiac hypertrophy that is dependent on their histone acetyltransferase activity. The Journal of Biological Chemistry. 2003; 278:6838-47.

40. Watson PA, Reusch JE, McCune SA, Leinwand LA, Luckey SW, Konhilas JP, Brown DA, Chicco AJ, Sparagna $\mathrm{GC}$, Long CS. Restoration of CREB function is linked to completion and stabilization of adaptive cardiac hypertrophy in response to exercise. Am J Physiol Heart Circ Physiol. 2007; 293:H246-H59.

41. Kim JY, Lee EY, Choi I, Kim J, Cho KH. Effects of the Particulate Matter2. 5 (PM2. 5) on Lipoprotein Metabolism,
Uptake and Degradation, and Embryo Toxicity. Molecules and Cells. 2015; 38:1096.

42. Xu X, Liu C, Xu Z, Tzan K, Zhong M, Wang A, Lippmann M, Chen LC, Rajagopalan S, Sun Q. Long-term exposure to ambient fine particulate pollution induces insulin resistance and mitochondrial alteration in adipose tissue. Toxicological Sciences. 2011; 124:88-98.

43. Sun Q, Yue P, Deiuliis JA, Lumeng CN, Kampfrath T, Mikolaj MB, Cai Y, Ostrowski MC, Lu B, Parthasarathy $\mathrm{S}$. Ambient air pollution exaggerates adipose inflammation and insulin resistance in a mouse model of diet-induced obesity. Circulation. 2009; 119:538-46.

44. Du Y, Xu X, Chu M, Guo Y, Wang J. Air particulate matter and cardiovascular disease: the epidemiological, biomedical and clinical evidence. Journal of Thoracic Disease. 2016; 8:E8.

45. Pope CA 3rd, Dockery DW. Health effects of fine particulate air pollution: lines that connect. Journal of the Air \& Waste Management Association. 2006; 56:709-42.

46. Huang L, Wang C, Zhang Y, Li J, Zhong Y, Zhou Y, Chen Y, Zuo Z. Benzo [a] pyrene exposure influences the cardiac development and the expression of cardiovascular relative genes in zebrafish (Daniorerio) embryos. Chemosphere. 2012; 87:369-75.

47. Lund AK, Goens MB, Kanagy NL, Walker MK. Cardiac hypertrophy in aryl hydrocarbon receptor null mice is correlated with elevated angiotensin II, endothelin-1, and mean arterial blood pressure. Toxicology and Applied Pharmacology. 2003; 193:177-87.

48. Gao W, Wang H, Zhang L, Cao Y, Bao JZ, Liu ZX, Wang LS, Yang Q, Lu X. Retinol-binding protein 4 induces cardiomyocyte hypertrophy by activating TLR4/MyD88 pathway. Endocrinology. 2016; 157:2282-93.

49. Lin YC, Huang J, Hileman S, Martin KH, Hull R, Davis $\mathrm{M}, \mathrm{Yu}$ HG. Leptin decreases heart rate associated with increased ventricular repolarization via its receptor. Am J Physiol Heart Circ Physiol. 2015; 309:H1731-H9.

50. Lin YC, Huang J, Kan H, Castranova V, Frisbee JC, Yu HG. Defective calcium inactivation causes long QT in obese insulin-resistant rat. Am J Physiol Heart Circ Physiol. 2012; 302:H1013-H22.

51. Huang J, Huang A, Zhang Q, Lin YC, Yu HG. Novel mechanism for suppression of hyperpolarization-activated cyclic nucleotide-gated pacemaker channels by receptorlike tyrosine phosphatase- $\alpha$. Journal of Molecular and Cellular Cardiology. 2008; 283:29912-9.

52. Phan NN, Wang CY, Lin YC. The novel regulations of MEF2A, CAMKK2, CALM3, and TNNI3 in ventricular hypertrophy induced by arsenic exposure in rats. Toxicology. 2014; 324:123-35. 